Portland State University

PDXScholar

\title{
Integrating Information Literacy, the POGIL Method, and iPads into a Foundational Studies Program
}

\author{
Carrie Moore \\ Boise State University \\ Jennifer Black \\ Boise State University \\ Barbara C. Glackin \\ Portland State University, bglackin@pdx.edu \\ Margie Ruppel \\ Boise State University \\ Elaine Watson \\ Boise State University
}

Follow this and additional works at: https://pdxscholar.library.pdx.edu/ulib_fac

Part of the Information Literacy Commons

Let us know how access to this document benefits you.

\section{Citation Details}

Moore, Carrie; Black, Jennifer; Glackin, Barbara C.; Ruppel, Margie; and Watson, Elaine, "Integrating Information Literacy, the POGIL Method, and iPads into a Foundational Studies Program" (2015). Library Faculty Publications and Presentations. 170.

https://pdxscholar.library.pdx.edu/ulib_fac/170

This Post-Print is brought to you for free and open access. It has been accepted for inclusion in Library Faculty Publications and Presentations by an authorized administrator of PDXScholar. Please contact us if we can make this document more accessible: pdxscholar@pdx.edu. 
Integrating Information Literacy, the POGIL Method, and iPads into a Foundational Studies Program

Carrie Moore, Head, Information and Research Services, Albertsons Library, Boise State University, 1910

University Dr., Boise, ID 83725-1430, USA

Email address: carriemoore1@boisestate.edu

Jennifer Black, Lecturer, English Department and Foundational Studies Program, Boise State University, 1910 University Dr., Boise, ID 83725-1430, USA

Email address: jblack@boisestate.edu

Barbara Glackin, Associate Dean, Public Services, Boise State University, 1910 University Dr., Boise, ID 83725-1430, USA ${ }^{1}$

${ }^{1}$ Present address: Assistant University Librarian for Resource Services \& Technology, Portland State

University Library, 1875 SW Park Avenue, Portland, OR 97201

Email address: barbaraglackin@pdx.edu

Margie Ruppel, Education Librarian, Albertsons Library, Boise State University, 1910 University Dr., Boise, ID 83725-1430, USA

Email address: margieruppel@boisestate.edu

Elaine Watson, Instruction Coordinator, Albertsons Library, Boise State University 1910 University Dr., Boise, ID 83725-1430, USA

Email address: ewatson@boisestate.edu

\section{Abstract}

This article provides an overview of the design, implementation, revision and informal

assessment of an information literacy curriculum embedded in a new University Foundations (UF)

program at a mid-sized public university. The library information literacy sessions incorporated team-

based learning and Process Oriented Guided Inquiry Learning (POGIL) elements using iPads. Each session

provided students an opportunity to develop and apply information literacy skills, and included critical

thinking questions which led students to think about underlying concepts. A focus group with the

librarians assessed the UF library curriculum, its impact on student engagement, and the training

activities for librarian teaching preparation. 
Keywords: team-based learning; information literacy instruction; iPads; Process Oriented Guided Inquiry Learning; mobile technology; inquiry-based learning

\section{Introduction}

This article focuses on Boise State University's development of an information literacy curriculum for two University Foundations courses using active learning techniques that incorporate iPads and the Process Oriented Guided Inquiry Learning (POGIL) method. Boise State University is a fouryear public institution with an enrollment of approximately 22,500 students. Academic librarians at Albertsons Library became involved in discussions about active learning and information literacy when the University reviewed its core curriculum and created new Foundational Studies courses, including University Foundations 100 (first year), University Foundations 200 (second year) and University Foundations 300 (transfer year), all of which include information literacy components.

POGIL is a teaching method that incorporates active, team-based learning. While active learning techniques have existed for some time in library instruction, use of the POGIL instruction technique in libraries has only been documented during the last few years (Mitchell and Hiatt, 2010; Loo, 2013). The librarians combined iPads with POGIL to facilitate instruction and make the library instruction program mobile and scalable. Following the first semester of implementing the new University Foundations (UF) library instruction sessions, the authors coordinated a focus group with 
librarians with the goal of improving the curriculum, increasing student engagement, and improving related librarian training activities.

\section{Literature Review}

This literature review covers literature from the past five years on embedded librarianship, active learning in undergraduate instruction, and iPads in library instruction. Recent literature on embedded librarianship focuses on relationship building, librarian responsibilities, and academic programs. Shumaker (2009) outlines ideas for moving librarians from the traditional role of service providers to being an integral part of the academic teaching and learning community. As Thull and Hansen (2009) suggest, faculty and librarians are becoming true partners in supporting teaching and student learning. They set the stage by theorizing that library liaisons best support student information needs by interacting with users where they are and by removing expectations that learners come to the physical library (Thull and Hansen, 2009). Anthony (2010) effectively explains that collaboration between faculty and librarians is essential, emphasizing that embedding information literacy into the academic curriculum benefits students' educational experiences through linking library instruction to classroom activities. Johnson, McCord and Walter (2003) take embedded librarianship to another level by moving from working with individual faculty and classes to exploring the advantages of a programmatic approach to teaching information literacy skills through library instruction. A key component of their concept is having librarians go into the classroom to teach research skills to help students learn to think critically about information. Targeting a defined population, this programmatic approach allows librarians an opportunity to directly impact the student educational experience on a scale previously not seen (Johnson, McCord and Walter, 2003).

Shifting towards a course-integrated approach to library instruction in academic libraries goes along with an increased trend towards using active learning techniques in the classroom. The value of active learning is endorsed by Detlor, Booker, Serenko and Julien's (2012) study that found even one 30- 
minute active information literacy instruction session resulted in improved student learning outcomes over that of passive information literacy instruction sessions. Hegarty, Carbery and Hurley (2009) incorporated active learning for first year students in the form of worksheets where students did handson activities in small groups on topics related to books, journals, and the catalog. Several articles mention the use of questions in library sessions using inquiry-based learning: Bogucka and Wood (2009) employed an active learning exercise with guided questions for paired nutritional sciences students to learn about research articles; Jones (2009) used questions in an information retrieval module; and Peters (2011) described use of guided exercises with "thought questions" in three chemistry courses where the students completed exercises in pairs. In 2011, McKinney, Jones and Turkington explored the use of an embedded inquiry-based learning activity in a Psychology course to improve information literacy skills. Peters (2011) and Jacobson (2011) showed the advantages of team-based learning in a required one-credit information literacy course.

One type of inquiry-based learning, which the Boise State University Foundations (UF) library instruction sessions are modeled on, is the POGIL (Process Oriented Guided Inquiry Learning) method. POGIL is a team-based, student-centered learning method that originated in college chemistry classrooms in the early 1990s where students work in teams to solve problems or work through guided, structured exercises. POGIL activities have three main characteristics: 1) "self-managed teams that employ the instructor as a facilitator of learning rather than as a source of information" (Moog and Spencer, 2008, p. 3); 2) activities that are designed around a learning cycle, consisting of an exploration phase, a concept invention/term introduction phase, and an application phase; and 3) subject-specific content along with process skills such as communication and critical thinking.

Hale and Mullen (2009) designed POGIL lesson plans for a marketing class, and Johnson (2011) detailed how to use the POGIL method to teach introductory German. Mitchell and Hiatt (2010) presented a case study for using the POGIL method in a one-credit information literacy course which 
consisted of three lesson plans: research topic identification and exploration; topic outline and resource identification; and resource evaluation. After the information literacy POGIL unit concluded, students indicated that the "active nature of learning these concepts and skills was preferable to other methods" (Mitchell and Hiatt, 2010, p. 541).

Loo (2013) discussed improving student learning of information literacy skills in a single-session chemistry class by using guided and team-based activities which incorporated process worksheets and POGIL elements. "Students gained practical hands-on experience in a guided fashion," with the librarian providing personalized learning support and observing student progress during class (2013, p. 258-259). Challenges identified by Loo include the extensive time needed to prepare guided worksheets, and the in-class time required to orient students to team-based learning during a brief library workshop (2013, p. 258).

POGIL's success has been assessed in a variety of ways, at several institutions. POGIL is shown to achieve the following, when compared to traditional teaching methods:

- Improve mastery of content and skills (Hanson and Wolfskill, 2000; Lewis and Lewis, 2005; Straumanis and Simon, 2006)

- Increase exam scores and course grades (Farrell, et al., 1999; Hanson and Wolfskill, 2000; Lewis and Lewis, 2005; Straumanis and Simon, 2006; Brown, 2010)

- Positively impact student proficiency on nationally standardized exams (Hein, 2012)

- Increase student perceptions of the importance of their peers in helping them to understand ideas and concepts (Brown, 2010)

- Lower course attrition rates (Farrell, et al., 1999; Hanson and Wolfskill, 2000; Straumanis and Simon, 2006)

Integrating iPads into academic library instruction has received little attention in the literature. Articles primarily focus on surveying students to see if they would use mobile devices, like iPads, to access library resources (Dresselhaus and Shrode, 2012) and on reference interactions where roving librarians use mobile devices to connect users to library services, databases, and materials (Sharman and Walsh, 2012). At Indiana University Purdue University Indianapolis, Miller (2012) discusses incorporating iPads across disciplines to support information literacy activities in one-shot instruction 
sessions. Starting with foundational information delivered by lecture, students had to use apps, the library mobile website, and web browsing to find materials related to a topic. Gibeault (2013) focused on using iPads to facilitate library instruction sessions in a SCALE-UP (Student Centered Active Learning Environment with Upside-down Pedagogies) classroom. "While presenting a few impermanent technical disadvantages, the iPad demonstrated support for active and collaborative learning approaches including: instant polling, the ability to share content, and the ability to navigate the library web page and databases" (Gibeault, 2013, p. 7).

\section{Foundational Studies Program and Library Collaboration}

The Foundational Studies Program at Boise State University was implemented in 2012, replacing the former Core Curriculum. In December 2008, a Core Reform Task Force convened to review and reform the general education requirements. Based on investigation of existing general education programs, including programs at peer universities, the Task Force developed a lengthy list of skills, knowledge, and characteristics that students should gain during their undergraduate experience. Upon identifying these ideals, the Task Force chose to model the new Boise State Foundational Studies Program on the Association of American Colleges and Universities' Liberal Education \& America's Promise (LEAP) initiative (Association of American Colleges and Universities, 2007). LEAP "is a national advocacy, campus action, and research initiative that champions the importance of a twenty-first century liberal education - for individuals and for a nation dependent on economic creativity and democratic vitality" (Association of American Colleges and Universities, n.d.).

The Foundational Studies Program focuses on eleven University Learning Outcomes (ULOs) which are a set of shared learning goals for all students earning degrees at Boise State. The ULOs 
include: writing; oral communication; critical inquiry; innovation and teamwork; ethics; diversity and internationalization; quantitative reasoning and mathematics; natural, physical, and applied sciences; visual and performing arts; literature and humanities; and social sciences (http://academics.boisestate.edu/fsp/university-learning-outcomes/). Three required shared experience courses are included in the Foundational Studies Program: UF 100 (University Foundations 100: Intellectual Foundations), UF 200 (Civic \& Ethical Foundations) and UF 300 (Transitional Foundations). UF 100 is required for all first year students; UF 200 is required for all second year students; and UF 300 is required for all transfer students. Additional Foundational Studies courses address the ULOs throughout a student's undergraduate college experience.

Faculty teams formed to create the University Foundations 100, 200 and 300 curricula. Since the Foundational Studies Program was a university-wide initiative, the Library's Associate Dean for Public Services was assigned to be the UF Library Liaison for each faculty team. The UF Library Liaison became the UF faculty members' "one-stop-shop" to library services, classroom/student instruction, research support, and resource information.

Critical inquiry was a key discussion point in UF lead faculty team meetings, which led to linking library instruction to the Foundational Studies courses. This connection was appropriate because of the relationship between critical inquiry and information literacy. Academic librarians follow the Association for College and Research Libraries (ACRL) Information Literacy Competency Standards for 
Higher Education (1996-2013), which include components integral to critical inquiry: locating, using and evaluating information.

As discussions of UF lead faculty teams progressed, the UF Library Liaison approached Library administration about the possibility of integrating library instruction into the UF 100, 200 and 300 classes. Library administrators discussed committing to and implementing a large-scale library instruction program, the scalability and sustainability of implementing a project of this scope and magnitude, and the impacts on existing library resources. The opportunity to directly interact with every new student on campus was the deciding factor to move forward. Library administrators met with the Foundational Studies Program director to discuss the librarians actively participating in UF courses, and the director was supportive of the idea. To fully support the new university UF initiative, face-to-face library instruction was shifted from one-shot library instruction sessions in the First Year Writing Program (English 101 and 102) and Communication 101 to library instruction sessions in the UF courses. Research skills previously taught in the English and Communication courses were incorporated into the UF library sessions. This decision was based on library staffing levels and scalability of the UF library curriculum.

A library team was formed to develop an instruction curriculum which focused on the research skills of finding and evaluating information. The Library Curriculum Team (hereafter referred to as the "Team") consisted of the head of information and research services, the instruction coordinator, and an instruction librarian experienced with using the POGIL (Process Oriented Guided Inquiry Learning) 
method of instruction. The UF Library Liaison facilitated communications between the Library

Curriculum Team and the UF lead faculty.

To ensure instructional consistency, the UF Library Liaison and the Team decided to create a

single library instruction curriculum for each library session in the University Foundations courses.

Additional early decisions included: integrating active learning and student teamwork into the sessions

(using POGIL); utilizing mobile devices for classroom instruction; designing the search examples around

the University's campus read book; and scheduling library sessions during consecutive weeks. The

scheduling caveat allowed for skills learned in-class to be practiced through out-of-class activities and

promoted continuity within the instruction. UF faculty requested library sessions for dates that

coincided with the research needs of their course.

\section{Creating the Curriculum}

The UF lead faculty identified ULOs for teamwork and critical inquiry as key components of the

UF 100 and 300 curricula, and the Library Curriculum Team built on these outcomes in developing its

team-based and inquiry-based library instruction. Experiences from previous library instructional

methods also informed the development of the new UF curriculum. One previous method involved the

Library 101 orientation for Introduction to College Writing (English 101) where students rotated through

several stations and participated in hands-on activities. The Library Curriculum Team liked the hands-on

approach to Library 101 because it created a classroom atmosphere with greater student-to-student

engagement. 
With the goal of creating a similar active learning experience in the UF library sessions, the Team decided to incorporate active learning into the curriculum. The strategies of connecting active learning to critical thinking skills and collaborating with UF lead faculty were in line with the Association of College \& Research Libraries' Guidelines for Instruction Programs in Academic Libraries:

"Instruction should employ active learning strategies and techniques that require learners to develop critical thinking skills in concert with information literacy skills. Planning such active learning strategies and techniques should be carried out collaboratively with faculty to increase overall student engagement and to extend opportunities for a more reflective approach to information retrieval, evaluation, and use" (2003, rev. 2011).

The Team developed the library instruction content for UF 100 and 300 in Spring 2012 with plans to teach the first classes in Fall 2012 (See Timeline in Table 1.1). In addition, a strategy for offering the same library instruction content for the online sections of UF 100 and 300 had to be designed, tested, and implemented. Video tutorials for the online sections were developed by the Digital Access Librarian and the library's instructional designer.

Table 1.1: Timeline for Library Curriculum Development and Integration

\begin{tabular}{|l|l|}
\hline February - August 2012 & UF 100 and 300 curriculum developed and approved \\
\hline April - August 2012 & Online video tutorials of Library UF curriculum scripted and \\
& created for the online UF sections \\
\hline
\end{tabular}




\begin{tabular}{|l|l|}
\hline June - August 2012 & Librarian training and technology logistics. Finalized UF 100 \\
& and 300 curriculum and librarian scripts \\
\hline Fall 2012 & UF 100 and 300 taught for the first time with library sessions \\
& taught in UF classrooms. UF 200 library curriculum developed \\
\hline September - December 2012 & UF faculty feedback \\
\hline November 2012 & Librarian focus group \\
\hline December 2012 & Curriculum revised for Spring 2013 \\
\hline Spring 2013 & UF 200 taught for the first time. Library sessions taught in UF \\
& 100,200 and 300 classrooms \\
\hline
\end{tabular}

The library's use of active learning took the form of inquiry-based and team-based learning to ensure students were engaged in the learning process. Research studies indicate “... students working in learning teams learn more; understand more; remember more; feel better about themselves and others; have more positive attitudes regarding the subject area, course, and instructors; and acquire critical thinking skills, cognitive learning strategies, and other process skills that are essential to their development as independent learners" (Moog, Creegan, Hanson, Spencer \& Straumanis, 2006, p. 43).

The theoretical underpinnings of learning teams rest on constructivist principles, where students "... are actively engaged and thinking in class; construct knowledge and draw conclusions themselves by analyzing data and discussing ideas; and learn how to work together to understand 
concepts and solve problems" (Farrell, Moog, \& Spencer, p. 570). A prominent feature of the POGIL

method is that students build their own knowledge through structured team activities; the instructor is not just a source of information, but a facilitator of learning. Small groups of students work collaboratively on a series of guided inquiry questions and critical thinking questions to learn a concept or skill.

POGIL helps students develop process skills such as critical thinking, problem solving, and communication, team participation, interpersonal skills, management, and self-assessment (Writing Process Skill Goals for POGIL Activities, n.d.). Each POGIL activity requires information processing, especially important for information literacy skills. Students take on designated roles within the team, such as spokesperson, technician, and manager, to ensure that all students are fully engaged in the learning process.

\section{Scaffolding Library Skills}

Deliberate thought was given to scaffolding library skills throughout the UF library curriculum.

This entailed providing multiple student touch points, with differentiated library learning experiences as they progressed through the Foundational Studies Program. Each touch point provided an opportunity to reinforce the earlier concepts, introduce new content and skills, and establish a foundation for future knowledge. Determining the amount of content to include in a forty-five-minute session was a challenge. For example, blocking out time for introductions, giving context to the activities, debriefing tasks, and reviewing out-of-class assignments meant that only three to four student team tasks could be 
incorporated into each session. Table 1.2 outlines the scaffolding of library skills presented to students

in UF instruction from first year through their final year of undergraduate education.

Table 1.2 Scaffolding of Library Skills in UF Instruction

- $\quad$ First Year (UF 100)

o Curriculum: [Session 1] Introduction to brainstorming key words and concept mapping, interdisciplinary database (Academic Search Premier) searching and tools, MLA citation style; [Session 2] website and article evaluation using the CRAAP criteria: Currency, Relevance, Authority, Accuracy, Purpose (Meriam Library, 2010).

o Additional Skills: critical thinking, teamwork development, using mobile devices.

- $\quad$ Second Year (UF 200)

o Curriculum: [1 Session] Developing search strings from brainstorming and concept mapping, advanced searching techniques in an interdisciplinary database (Academic Search Premier), database searching and tools (advanced skills, Web of Science), finding statistical information, and locating subject specific databases using LibGuides.

o Additional Skills: critical thinking, teamwork development, using mobile devices.

- $\quad$ Transfer Students (UF 300)

o Curriculum: [Session 1] Introduction to brainstorming key words and concept mapping, interdisciplinary database (Academic Search Premier) searching and tools, APA citation style; [Session 2] website and article evaluation using the CRAAP criteria 


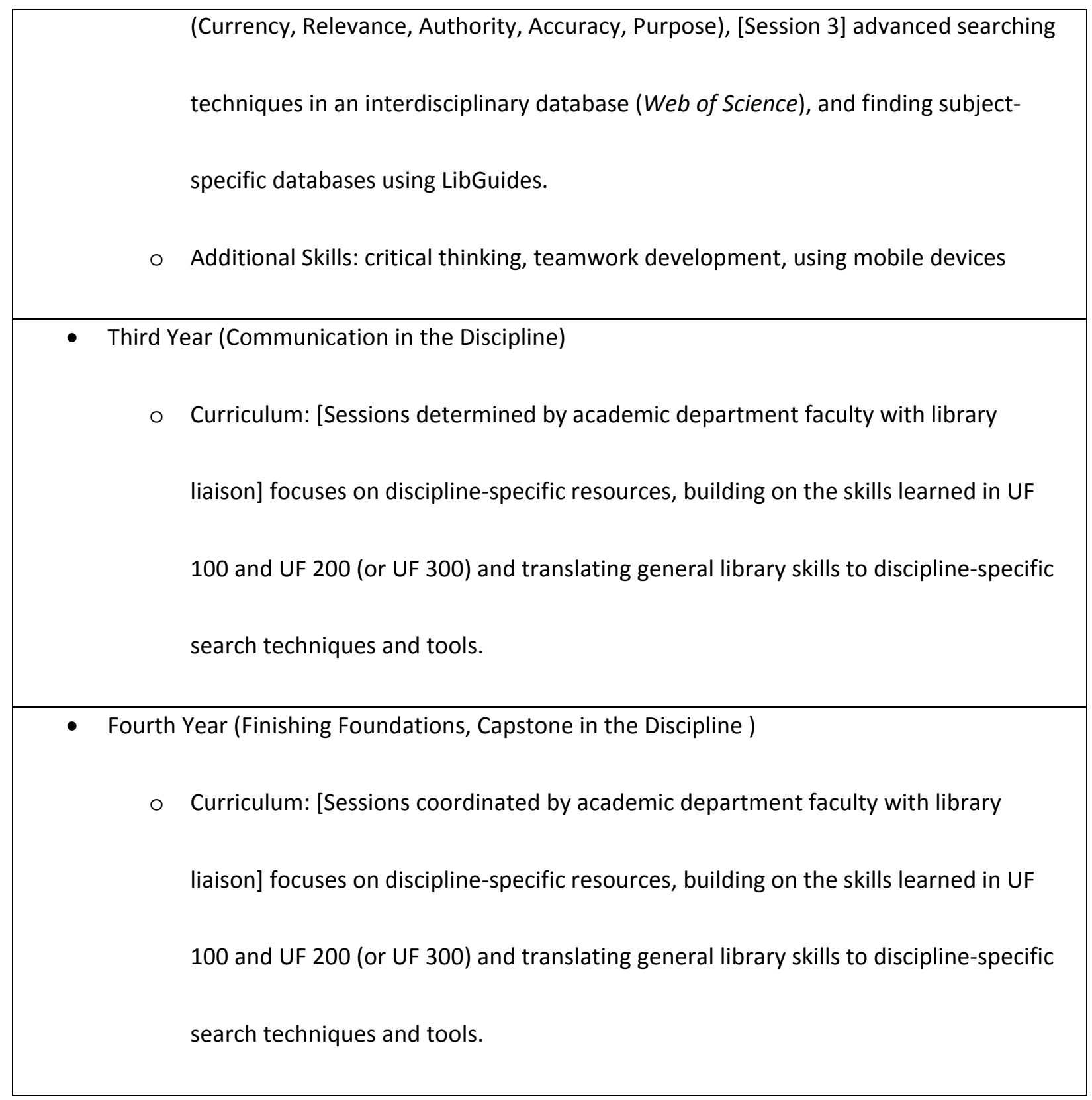

The Library Curriculum Team created instruction materials for each library session: a student inclass activity sheet, an out-of-class assignment sheet, and the librarians' script. At the beginning of each session, the librarian set the stage by presenting the learning objectives, initiating a dialogue with the students to establish rapport, and starting the guided inquiry process. Following the step-by-step 
instructions, student teams worked together on team tasks (see Appendix 1 UF Image 1.1 Example Team

Task), learning skills and concepts, and answering critical thinking questions.

Image 1.1 Example Team Task from UF100 Session 2 


\section{Team Task \#2: Evaluate Two Articles (8 min.) and Debrief (7 min.)}

\section{Instructions:}

Each team will evaluate two articles (one peer-reviewed article and one magazine article):

1. The scholarly article (Article A) is the one your team selected in Task \#1.

2. The librarian will provide your team with Article B.

\section{Critical Thinking Questions (answer for each article):}

a) Who is the author(s) of the article? What are their qualifications?

Article A:

Article B:

b) When was the article published?

Article A:

Article B:

c) Who is the intended audience? How do you know?

Article A:

Article B:

d) How is the information in the article supported by evidence?

Article A:

Article B:

e) Which article is more authoritative? Support your answer.

f) Would you be comfortable using both of these articles for a research paper? Why/why not? 
Team tasks were allotted short amounts of time for students' completion to keep each session

fast-paced. While student teams worked independently, the librarian periodically checked-in to confirm they were on task. During this time, the librarian did not answer any question the student teams could reasonably answer on their own, but sometimes gave help to teams that were stumped. While this technique is a feature of POGIL, it encourages team members to work hard at each task, rather than asking the librarian for help. Following each team task, the librarian facilitated a debriefing where student teams shared their answers to selected critical thinking questions. The librarian clarified any misunderstandings during the debriefings, ensuring the learning objectives were met, and answered additional questions from students.

The Library was also responsible for scripting and creating a curriculum for the online UF courses. This online library curriculum mirrored the face-to-face instruction so students would have a similar team learning experience. Collaboration between the library's curriculum and online instructional design teams resulted in scripting and creating the video tutorials. These tutorials were an important component of the online instruction curriculum, and included separate videos for each team's task introduction, instructions, and debrief. The online library curriculum included students working on team tasks together and completing individual assignments.

\section{Mobile Learning and iPads}


In fall 2011, Boise State University committed to exploring effective means to integrate mobile learning and teaching into the student education experience. This commitment produced the Mobile Learning Initiative, a two-year project to aggressively integrate mobile learning activities and devices into the faculty teaching experience and the student learning experience through strategic inclusion of mobile technology into the classroom experience. Albertsons Library was at the forefront of the University's mobile investigations. All librarians were provided with iPads to incorporate into their work, and eventually all library staff members were given mobile devices (Aagard, Armstrong, Cooper, \& Nuxoll, 2013). Due to the Mobile Learning Initiative, the groundwork was already in place to use iPads in the UF library curriculum, and the University community was open to the exploration of new learning opportunities provided by integration of mobile devices into the classroom.

Library administrators supported the use of iPads for UF instruction because of librarian familiarity with iPad features and functionality. iPads seemed a logical choice for facilitating active engagement in students' own classrooms due to the iPad's size and portability. Incorporating mobile devices also aligned with the University's mission of increasing digital literacy skills. The Library's commitment to the UF instruction program required the purchase of additional iPads and the support of the entire library.

In Fall 2012, the Library planned to do instruction for approximately 152 UF 100 sessions and 22 UF 300 sessions, with an understanding that these numbers would increase with the addition of UF 200 in Spring 2013. To accommodate the number of library instruction sessions, 19 full-time librarians in the 
following units participated: Reference and Instruction, Special Collections and Archives, Access

Services, Cataloging, ScholarWorks, Digital Access Services, and the Associate Dean for Public Services.

Once instruction began in Fall 2012, librarians outside of the Reference and Instruction unit also helped with staffing the reference desk when the schedule was intense.

\section{Implementing the UF Library Instruction}

Implementing the curriculum involved a script and multiple practice sessions for librarians, the assistance of many library staff members, and the creation of a detailed instruction schedule. To

provide a similar learning experience to the approximately 3,900 UF students, the Library Curriculum

Team created an instruction script for librarians (which resulted in consistently teaching the same

learning objectives. The script included librarian talking points alongside the student worksheet (see

Appendix 1). Once the librarian scripts and student materials were drafted, the curriculum team

provided demonstration sessions of the two UF 100 and three UF 300 sessions. There was some

librarian apprehension about what was and was not included in the curriculum, teaching students in

teams, taking iPads to the classroom, and the need to follow the shared script. In recognition of this

apprehension, extensive practice and preparation occurred.

Throughout the summer, librarians practiced teaching the UF sessions to a student population

made up of library staff and student employees. This allowed individual librarians to gain experience

with teaching the content, prepare for 'live' sessions, and become comfortable with the curriculum

format. A Library Curriculum Team member attended each practice session and provided librarian 
instructors with feedback about their teaching. Teacher and student comments on the content, timing, and delivery of the curriculum resulted in an evolving script that was finalized in late summer. There were many "aha" moments at the practice sessions, which translated into teaching tips and ways to be more efficient with the curriculum.

Librarians successfully adapted to three significant changes in instruction during these practice sessions. Using mobile devices in the classroom was the first change. Although the librarians were familiar with iPads, there was some initial apprehension about incorporating iPads into instruction. Second, the librarians had to familiarize themselves with the curriculum content and follow the instruction script. Lastly, the librarians learned to facilitate cooperative group work using POGIL in the classroom, a pedagogical shift from previous instruction for many of the librarians. Through the practice sessions, the librarians became less apprehensive with mobile devices in the classroom and using a new teaching style.

Other library staff members played a crucial role in preparing to implement UF instruction. Once the session scripts were drafted, staff members outside of the reference and instruction unit proofread documents, participated in practice sessions as students, and provided feedback about content and curriculum materials. Library Computer Services staff designed and supported a workflow for efficiently maintaining the iPads used for instruction. In addition, Technical Services staff created the closed-captioning transcripts for the online video tutorials. 
One library staff member, designated the mobile device coordinator, was assigned to manage the scheduling, imaging, and maintaining of the iPads. The coordinator was responsible for preparing instruction materials for each session, which included: iPads (1-2 per team), student activity sheets, team role cards, laser pointer, headphones, and a listing with faculty name/classroom location/and class start and end times. The materials also contained a guide for changing the settings on the iPad for patrons needing to modify audio or visual settings to meet accessibility needs. The mobile device coordinator played a significant support role by allowing librarians to focus on teaching and not worry about instruction materials. A second staff person was trained and served as the backup for preparing the instruction materials. For student privacy reasons, iPads were reimaged following each session to the original instruction image profile. If multiple sessions were held back-to-back, reimaging was done at the end of the day.

The creation of the instruction schedule (Image 1.2) was critical due to the large number of overlapping sessions and the objective of not having the same librarian teach the same class twice. In exposing students to multiple librarians, the objective was to have students feel comfortable asking any librarian a question when they came to the library. Scheduling logistics required constant communication and negotiation between UF faculty and the UF Library Liaison as faculty set date(s) for the in-person library sessions to align with their course content. The UF library sessions were scheduled to take place back-to-back during classes that met once a week (for example, the three UF 300 sessions were presented during a single class). Back-to-back library sessions were also scheduled for hybrid 
courses, which met every other week face-to-face and online on alternate weeks, and for distance

courses requiring librarian travel.

\section{Image 1.2 UF Instruction Schedule}

\begin{tabular}{|c|c|c|c|}
\hline & 19-Sep & Team Size & \\
\hline Session 2 & 7:30-8:20 Woods/Lundy (Educ 320) & 4 or $5(25)$ & Michelle \\
\hline Session 2 & 7:30-8:20 Woods/Murphy (Educ 317) & 4 or $5(25)$ & Cheri \\
\hline Session 2 & 7:55-8:45 Woods/Wood (Multip 210) & 4 or $5(25)$ & Julia \\
\hline Session 2 & 9:00-9:50 Woods/Murphy (Micron Bus/Econ 110 & 4 or $5(25)$ & Megan \\
\hline Session 2 & 9:00-9:50 Woods/Ness (Bus 102A) & 4 or $5(25)$ & Melissa \\
\hline Session 2 & 9:00-9:50 Woods/ (Keiser Res Hall, Rm 103) & 4 or $5(25)$ & Kelsey \\
\hline Session 2 & 9:00-9:50 Woods/Budd (Multip 207) & 4 or $5(25)$ & Margie \\
\hline Session 2 & 9:00-9:50 Woods/Moore (Educ 223) & 4 or $5(25)$ & Kent \\
\hline Session 2 & 9:00-9:50 Woods/Nichol (ILC 213) & 4 or $5(25)$ & Terry \\
\hline Session 2 & 2:00-2:45 Stockton/Stockton (ILC 213) & $8(24)$ & Megan \\
\hline Session 2 & 2:00-2:45 Stockton/Furman (Educ 317) & $8(24)$ & Carolyn \\
\hline Session 2 & 2:00-2:45 Stockton/Martini (Lib203) & $8(24)$ & Melissa \\
\hline Session 2 & 2:00-2:45 Stockton/Jones (Lib201C) & $8(24)$ & Marilia \\
\hline Session 2 & 3:30-4:15 Stockton/Jones (Lib201C) & $8(24)$ & Kelsey/Ellie \\
\hline Session 2 & 3:30-4:15 Stockton/Caldwell-O'Keefe (Educ 317) & $8(24)$ & Terry \\
\hline Session 2 & 6:30-7:15 Stockton/White (Multip 210) & $8(24)$ & Elaine \\
\hline
\end{tabular}

Following months of preparation, UF library instruction started in September 2012. Initiating a

project of this magnitude was daunting but a successful start soon helped the librarians become

confident and comfortable in the classroom. Librarians learned the peculiarities of classroom time

management, adjusted to working from the shared script, and there were some exciting teaching

moments between librarians and students. Of course, minor glitches occurred, for example, a seven 
floor building with instruction on the fourth floor and a non-working elevator, and a class that moved across campus without sharing the new location, but overall the library sessions went well. From the beginning, librarians shared good and bad classroom experiences with one another formally and informally. This sharing enabled the librarians to adapt their teaching techniques to improve upcoming sessions and helped to create a team atmosphere. In addition, individual librarians made small tweaks to their instruction, such as not using the timers; changing when to distribute the iPads; and reducing the number of defined POGIL student roles.

During the first semester, teamwork within the library crossed traditional unit boundaries and involvement by all library staff was key to success. There was a shared sense of purpose regarding the Library's commitment to University Foundations. For the first time, the whole library was involved in the success of a multi-year campus program. The Library directly contributed to meeting the University Learning Objectives.

\section{Revising the Curriculum}

The Team began gathering feedback about the UF sessions and curriculum materials shortly after the librarians started teaching in fall 2012. A Google document was created for librarians to note concerns, make suggestions, and recommend edits for the teaching materials. Three brainstorming meetings provided an opportunity for librarians to discuss what was working, not working, and to suggest revisions. Librarians had a formal opportunity to provide feedback at a focus group coordinated 
by the Team. In addition, University Foundations lead faculty shared their comments about the curriculum with the UF Library Liaison.

\section{Focus Group}

The first UF library curriculum assessment project occurred in November 2012. The Library Curriculum Team secured approval from the University Institutional Review Board (IRB) to conduct a focus group with librarians about the UF instruction project. Using a modified Delphi technique, the focus group qualitatively investigated:

1. Librarians' perceptions of student engagement and understanding of UF library instruction session(s) content;

2. Improvements that could be made to positively impact the UF instruction sessions; and

3. Library faculty support, practice, and preparation for teaching the UF instruction curriculum.

The Delphi method is designed to bring together 7-15 experts to explore a topic (Donohoe \& Needham, 2009). Boise State librarians served as experts for this focus group, due to their experience with providing instruction in various setting and with teaching the UF curriculum during the fall semester.

Thirteen librarians participated in the focus group, which by using the Delphi method, provided an opportunity to come to consensus on judgments and decisions needed to improve the UF library instruction curriculum. In addition, this method helps avoid distractions inherent in unguided discussions (Donohoe \& Needham, 2009).

A major characteristic of the Delphi method is its iterative process. The first round asks participants to answer questions individually. The answers are shared with the larger group, and participants can then decide whether to alter their answer or keep the same answer. During the second 
round, the participants answer the questions individually again. The Delphi method calls for 3-4 rounds, in order to allow consensus to form. Two rounds are sufficient, however, if consensus has been reached (Donohoe \& Needham, 2009).

In the UF library instruction focus group, the librarians were asked to individually answer these four questions in round one:

1. What are your perceptions of students' engagement and understanding of the content in the library sessions?

2. What worked in preparing you to do library instruction for the University Foundations sessions?

3. What did not work in preparing you to do library instruction for the University Foundations sessions?

4. Please discuss what might be done differently to positively impact the library instruction sessions.

Individual responses were then shared with the larger group, followed by facilitated discussion about each question. After the discussion, the librarians individually answered questions two through four a second time. Question one was not included in round two because it asked the librarians' perceptions and it seemed redundant to cover the topic again.

To promote participation and open discussion, the Library Curriculum Team and the UF Library Liaison did not attend the focus group. The Director of the School of Social Work, experienced in conducting focus group sessions, agreed to facilitate the conversation. Bias was mitigated as the Director had not participated in any phase of the Library's UF curriculum design, implementation, or classroom instruction. Anonymity was assured by a School of Social Work assistant providing a typewritten record of the librarians' focus group discussion. The Delphi protocol provided an opportunity for the librarians' most salient responses to be identified. The authors reviewed the comments and coded 
the responses into four categories: 1) librarian preparation, 2) UF 100 faculty, 3) curriculum, and 4) technology.

Librarian preparation: The majority of focus group commentary centered on preparations for creating and offering UF library instruction. Statements on the organization of instruction materials and imaging of the iPads were favorable. Librarians noted how helpful the practice instruction sessions were in providing an opportunity to rehearse teaching the library instruction sessions, including the difficulty of classroom time management. Particularly helpful during the practice sessions were comments librarians provided one another on teaching styles and best practices. Continuing to share techniques throughout the semester on how to facilitate students working in teams, how to maximize classroom time, and how to engage students in activities, were thought to be valuable.

A few librarians mentioned their non-involvement with creating the curriculum as a negative. There were pro and con statements about use of a shared script for each individual UF session. Some librarians appreciated having an outline detailing how to facilitate the class. Other librarians were uncomfortable with using the full teaching script and would have preferred more classroom autonomy. A few remarks noted that although the intent was to follow the script carefully, reality sometimes required flexibility. The structure of the shared script was difficult to read and interpret in a live classroom situation and this resulted in either lots of highlighting of key concepts or creating one's own script. 
UF 100 faculty: Focus group participants identified communication between librarians and

discussion group leaders as an area needing improvement. Librarians were concerned that discussion leaders had not received sufficient information about the UF library instruction curriculum and the role of librarians in the classroom. Another comment involved timing of the library instruction. When the library instruction was scheduled during the last half of the class period, there were times when the discussion group class time impacted the forty-five minutes needed for library instruction.

Curriculum: The UF library instruction curriculum received numerous comments related to student engagement, the amount of content in the sessions, and the websites evaluated. Focus group participants noted that the curriculum contained good learning objectives and lesson plans. Regarding student engagement, they recommended the critical thinking questions be more challenging and have a higher degree of difficulty. It was noted that implementation of this recommendation could be problematic for students with greatly differing skill sets. Adding more interactive or audiovisual elements to the curriculum could have also increased the level of student engagement. The UF library instruction curriculum was tied to the Campus Read book, which presented themes of ecology and environmentalism. Librarians found that many UF students had not read the book and suggested the search examples not be linked to the Campus Read.

Although the Library Curriculum Team had calculated time for each session's activities, some librarians mentioned that UF100/300 session 2 included more content than could be comfortably addressed in the 45-minute session. The majority of the session 2 curriculum comments centered on 
the websites selected for comparative evaluation purposes. One of the websites, a fact sheet in PDF

format, was viewed as a poor choice because it did not include typical website features such as a

header, footer, and clickable links.

Technology: The major technology barrier that occurred during UF library instruction involved the iPad as an instructor's classroom tool. Librarians taught in classrooms throughout campus, where technology set-up occasionally caused frustration. The preference would have been to use the existing instructor workstation, rather than project the librarian's iPad. Inconsistent wifi connectivity across campus was also reported as an issue.

\section{Discussion}

This paper discusses the creation of an information literacy component in new University Foundations courses (UF 100 and UF 300) that commenced in Fall 2012. The curriculum for the library sessions incorporated active learning, the POGIL method, iPads, and student teams to teach information literacy skills. Overall, the first semester of teaching the new library curriculum went well due to the extensive preparation and commitment by the Library staff.

The use of POGIL and iPads in the library sessions improved the students' information literacy skills through critical thinking, problem-solving, communication and team participation. In the team tasks, students explored resources and practiced research skills using guided questions, rather than the librarian leading them through each step, and they also gained technology skills. The debriefing sessions 
allowed librarians to determine what the students had learned in the team task, and provide additional information to them as needed. In addition, the use of iPads allowed for mobile instruction with the librarians going to the classrooms, and enabled the instruction to be scalable because only a small number of iPads were needed for each class.

UF faculty were pleased with the scholarly articles and other resources that students integrated into their assignments. Anecdotal evidence from UF students, as conveyed to librarians, indicated they were more comfortable asking questions at the reference desk. They also appreciated the opportunity to meet librarians and learn how to use library resources early in their college careers. Students said they were able to replicate and use their research skills in other courses. Anecdotal comments from librarians indicated student questions at the reference desk were higher level, and it appeared that students had comprehended the skills taught in the UF library sessions.

In addition to the benefits noted by students, faculty members and librarians, the Library's UF instruction positively impacted librarians' information literacy instruction in their subject areas. Librarians are increasingly redesigning these instruction sessions to incorporate critical inquiry, teamwork and iPads. The consensus from librarians is this method of teaching library research skills is more effective and students are more engaged.

Although the librarians were initially apprehensive about the new instruction program and the use of iPads, their concerns were alleviated by the summer practice sessions, an iPad technology session to learn how to connect their iPads to the classroom equipment, and the experience of teaching the UF 
sessions in the Fall semester. Once the instruction sessions began, librarians shared tips with each other via email to smooth out any wrinkles. Librarians were also able to share comments for improving the library instruction materials (librarian scripts and student worksheets) in a Google document and in a librarian focus group. Newly hired librarians are given the opportunity to practice using the librarian script and to team teach prior to teaching on their own.

The librarians' focus group comments and feedback in the Google document informed both short- and long-term modifications to the UF library instruction content. Short-term changes included the timing of library instruction during longer UF sessions, reformatting the librarians' scripts, and replacing the websites used for evaluation. Long-term adjustments involved carefully balancing the curricular difficulty and incorporating more challenging critical thinking questions. With comments both in favor of, and against the shared script, a decision was made to retain the script. The shared script ensures scalability, facilitates student team work logistics, and provides quality control. Modifying the UF library instruction timing, librarians' scripts, websites, and curricular difficulty will create a more cohesive, challenging learning experience for students in future semesters.

There is ongoing communication between the library and UF faculty regarding curriculum revision and scheduling. Going forward, the library curriculum and videos for the online sections will be updated annually to incorporate search examples that align with each year's new Campus Read selection, and to make any changes to the library instruction curriculum based on comments from UF 
instructors, students and librarians. Minor curriculum changes will be made if needed during the intersession between the Fall and Spring semesters.

\section{Conclusion}

As a result of the Library's collaboration with the University's Foundational Studies Program, the Library and the UF information literacy curriculum has become an integral part of the educational experience for all incoming students and had a positive impact on student learning. The Information literacy instruction, linking learning activities directly to student assignments, was advantageous to skill mastery, retention, and transference. Strategically scaffolding these information literacy skills throughout the students' educational experience provided a platform for student success. The desired outcome for providing consistent library instruction to $1^{\text {st }}$ and $2^{\text {nd }}$ year students in the UF Program is that librarians are able to teach higher level information literacy skills to students in their $3^{\text {rd }}$ and $4^{\text {th }}$ year subject-specific courses, resulting in students' increased ability to effectively gather, evaluate and use information.

Incorporating POGIL's team- and inquiry-based methodology increased student engagement, and using iPads allowed the UF library instruction curriculum to be mobile and scalable. The POGIL method provided students with experience in critical thinking, problem-solving, and communicating and working in teams, all of which are designated University Learning Outcomes in the 
UF courses. Using iPads allowed students to easily work in teams, gain experience using mobile technology, and allowed librarians to take their instruction to classrooms across campus.

Systematic review and updating of the library's curriculum, with feedback from UF faculty, students and librarians, ensures that the instructional content will remain relevant from year to year.

Continuing assessment of the Library UF instruction curriculum and program will include student surveys and additional focus groups. This ongoing review and assessment is necessary for the Library's UF curriculum to continue to have a positive impact on student learning. 


\section{UF 100 Session 2 \\ Librarian Script \\ Evaluating Articles \& Websites}

Take with you:

- Your iPad and connection cords

- Librarian script

- Timer

- Copies of UF 100 Session 2 Student Worksheet and UF 100 Session 2 Out of Class Activity

- One device for each group

- Laminated cards with group roles

- Copies of magazine article (Article B) for Team Task \#1 - one copy for each group

Total time for session is $\mathbf{4 5} \mathrm{min}$. - Do not exceed.

\begin{tabular}{|l|l|}
\hline Librarian Script & Student Worksheet \\
\hline Before the class starts: & \\
1. Password \\
Note: Students can see your password \\
as you are typing it in, so if you have to \\
type in your password during class, \\
you may want to disconnect the iPad \\
from the projector. \\
2. Identify Due Date for Out of Class \\
Activity $\rightarrow$ Ask Discussion Leader & \\
3. Hand out Student Worksheets. & \\
Ask Questions \\
"When you do a Google search, how \\
many of you know how to choose a \\
good web site?" \\
"Would you like to make this process a \\
lot faster and find the best web sites \\
right away?"
\end{tabular}




\section{INTRODUCTION \& OVERVIEW (2 min.)}

Introduction

- Librarian introduces themselves.

- Librarian briefly explains why we are there: to introduce the importance of evaluating resources (Librarian elaborate as desired.)

\section{Overview:}

- Librarian does overview of session goal and learning objectives: three team Tasks, and a discussion of the out-of-class activity.

DEVICES and GROUP ROLES (2 min.)

- Hand out devices (one for each team).

- Give each team a set of group role cards, and explain roles: Spokesperson, Manager, Technician, Materials Gatherer and Time-keeper.

- Emphasize that all students need to write answers on their worksheet for all tasks.

TEAM TASK \#1 (3 min.)

- Tell them they will have 3 minutes to complete Team Task \#1 and answer the critical thinking question.

- Walk around and listen to groups while they are working. Listen for things that seem easy, and for those that seem difficult
Goal: Students will learn skills for critically evaluating the reliability of articles and web sites.

Learning Objectives:

- Distinguish between articles from peerreviewed journals and from popular magazines.

- Explore the CRAAP criteria to evaluate articles and web sites.

Albertsons Library web site and Help Options:

http://library. boisestate.edu

UF 100 Subject guide:

http://quides. boisestate,edu/uf100
Team Task \#1: Pre-Evaluation of Article (3 min.) and Debrief (1 min.)

Instructions:

1. Compare your team's peer-reviewed articles, and choose the article that you think is most scholarly/academic. This article will be used for Team Task \#2.

2. Write a big " $\mathrm{A}^{x}$ on this article. This is Article A 
DEBRIEF - TEAM TASK \#1 (1 min.)

- Ask the one team's Spokesperson to answer CTQ. If you have time, ask one more team (spokesperson) to respond.

- Explain that they are already on their way to learning how to evaluate

information. In the next two team tasks, they are going to learn even more about evaluating info... (Librarian elaborate as desired)

TEAM TASK \#2 (8 min.)

- The scholarly article (Article A) is the one their team just selected in Team Task \#1

- The librarian will pass out Article B to each team: "Wildlife \& Ecosystem." Ecologist 39.6 (2009): 24. Environment Complete. Web. 6 Aug. 2012.

- Tell them they will have 8 minutes to complete Team Task \#2, and answer the critical thinking questions.

- Write the time on the board when they should be finished.

- Walk around and listen to groups while they are working. Listen for things that seem easy, and for those that seem difficult.
Critical Thinking Question (CTQ):

- What criteria did your team use to select the most scholarly article?
Team Task \#2: Evaluate Two Articles (8 min.) and Debrief (7 min.)

Instructions:

Each team will evaluate two articles (one peerreviewed article $[A]$ and one magazine article $[B]$ ):

1. The scholarly article (Article A) is the one your team selected in Task \#1.

2. The librarian will provide your team with Article B. 
DEBRIEF - TEAM TASK \#2 (7 min.)

- Ask the spokespersons to answer CTQ (a) and (f). If you have time, ask one more team's spokesperson to respond.

- As a follow-up to talking about the Authority part of evaluating information, discuss with the class as a whole what peer-review means. (Librarian elaborate.)

- Show the class the CRAAP criteria on the UF100 Site. Go to the Library Sessions tab and scroll down. Leave it up on the screen for when they work on Team Task \#3.

- Explain the CRAAP criteria. Tell the students that they just learned about the CRAAP concepts in Team Task \#2 and that they will be applying the CRAAP criteria in Team Task \#3.

$\mathrm{C}=$ Currency

$\mathrm{R}=$ Relevance

A=Authority

$\mathrm{A}=\mathrm{Accuracy}$

$\mathrm{P}=$ Purpose

TEAM TASK \#3 (10 min.)

- Tell them they will have $\mathbf{1 0}$ minutes to complete Team Task \#3 on their worksheets. In Team Task \#3 students will evaluate two websites, answer Critical Thinking Questions (CTQs) and choose a survivor website.

- Explain how to get to the websites on their devices.

- Students shouldn't have to login to Bronco Wireless because their devices will already be logged into Bronco-Guest.

- Write the time on the board when they should be finished.

- Walk around and listen to groups while they are working.
Critical Thinking Questions (answer for each article):

a) Who is the author(s) of the article? What are their qualifications?

Article A:

Article B:

b) When was the article published? Article A:

Article B:

c) Who is the intended audience? How do you know? Article A: Article B:

d) How is the information in the article supported by evidence? Article A: Article B:

e) Which article is more authoritative? Support your answer.

f) Would you be comfortable using both of these articles for a research paper? Why/why not?
Team Task \#3: Evaluate two web sites (10 min.) and Debrief (5 min.)

Instructions:

1. Using the links on your device's home screen, go to the web sites below.

2. Evaluate each web site using the critical thinking questions below to determine which is best and survives the evaluation.

Web site A: Footprint Basics (Global Footprint Network) (http://www.footprintnetwork.org/en/index. php/GFN/page/footprint basics overview/)

Web site B: Carbon Footprints Factsheets (Center for Sustainable Systems)

http://css.snre.umich.edu/css doc/CSS09 -05.pdf) 
DEBRIEF - TEAM TASK \#3 (5 min.)

- Ask each team to share their "Survivor" web site, and their reasoning. (Use whiteboard to report team's website ratings, if available.)

Ask the whole class:

- "What is challenging about evaluating information, and why is it an important part of doing research?"

- "How will this change your research habits in the future?"
Critical Thinking Questions (CTQs):

Each team will answer the following questions about the two web sites.

a) When was the web site published or last updated? (CURRENCY)

Web site A:

Web site B:

b) Who is the author or source of the information? What are their qualifications to write on the topic? What does the URL reveal about the author or source? (AUTHORITY)

Web site $A$ :

Web site $B$ :

C) Who is the intended audience? (PURPOSE)

Web site A:

Web site $B$ :

d) Is the information supported by evidence? What evidence? (ACCURACY) Web site A:

Web site $B$ :

Based on your evaluation of each web site, rate Web sites $A$ and $B$ from 1-4:

(RELEVANCE):

$4=$ very reliable web site

$3=$ reliable web site

2= unreliable web site

$1=$ very unreliable web site

Web site $A$ rating:

Web site $B$ rating:

e) Based on your team's evaluation and ratings of each web site, which one would be the survivor or the site you judged to be the best?

f) Would you be comfortable using your survivor web site for a research paper? Please be prepared to support your answer when reporting to the class. 
EXPLAIN OUT OF CLASS ACTIVITY (2 min.)

- Hand out Out of Class Activity.

- Emphasize that this assignment is turned in to their Discussion Leader, not the librarian.

- Tell the students what the due date will be (from Discussion Leader) and have them write it on the activity sheet.

- Quickly go through the steps in the assignment and tell them that the CRAAP Test is on the back of their Out of Class Activity.

- Remind students:

- The UF 100 subject guide is linked on their Blackboard course site and includes a link to Academic Search Premier.

- Go to the Library Sessions tab on the guide to find the CRAAP Test and MLA citation examples.

- Go over the ways of getting help at the library.

- Collect devices (iPads) from the students.
Out of Class Individual Activity

Due Date:

In this activity, you will find one new website and one new article and evaluate them using the five CRAAP criteria elements: currency, relevancy, authority, accuracy, and purpose. You will send your Discussion Leader the MLA citations for your two new sources and a brief summary of what you learned about the reliability of the sources after doing the CRAAP evaluation (200250 words).

\section{Complete these steps:}

1. Locate one new website and one new article, using Academic Search Premier to locate your new article. There is a link to this database on your UF 100 subject guide: http://quides boisestate.edu/uf100.

2. Familiarize yourself with the contents of each source.

3. Evaluate the website and the article using the five CRAAP criteria elements (see back of sheet)

4. Think about what you have learned about the reliability of sources.

5. In 200-250 words total, explain what you discovered about the reliability of the new website and the new article.

6. Cite the new website and the new article in MLA format. (The UF 100 subject guide can help you with this.)

7. Send your UF 100 Discussion Leader the MLA citations for these two resources, and your 200-250 word explanation about their reliability

If you need help:

- For help with this assignment, feel free to ask a librarian via text, chat, phone or FAQ at: http//library.boisestate edu/reference.php

- The UF 100 subject guide is linked on your UF 100 Blackboard site or go to http-//quides.boisestate edu/uf100.

- You can check out iPads, laptops, MacBooks and Netbooks at the library.

- Albertsons Library web site: http//library boisestate edu/ 


\section{References}

Aagard, M., Armstrong, M., Cooper, P., \& Nuxoll, R. (2013). iPads for all: Experiencing the unexpected. College \& Research Libraries News, 74(1),18-20. Retrieved from http://crln.acrl.org/content/74/1/18.full

ACRL Board of Directors (2003, rev. 2011). Guidelines for instruction programs in academic libraries. Association of College \& Research Libraries. Retrieved from http://www.ala.org/acrl/standards/guidelinesinstruction

Association of American Colleges \& Universities (2007). Introduction to LEAP: Liberal education \& America's promise: Excellence for everyone as a nation goes to college. Retrieved from http://www.aacu.org/leap/documents/Introduction to LEAP.pdf

Association of American Colleges \& Universities (n.d.). About Leap. Retrieved from https://www.aacu.org/leap

Association of College and Research Libraries (1996-2013). ACRL information literacy competency standards for higher education. Association of College \& Research Libraries. Retrieved from http://www.ala.org/acrl/standards/informationliteracycompetency

Anthony, K. (2010). Reconnecting the disconnects: Library outreach to faculty as addressed in the literature. College \& Undergraduate Libraries, 17(1), 79-92.

Bogucka, R., \& Wood, E. (2009). How to read scientific research articles: A hands-on classroom exercise. Issues in Science \& Technology Librarianship, (59), 4. 
Brown, P.P. (2010). Process-Oriented Guided-Inquiry Learning in an introductory anatomy and physiology course with a diverse student population." Advances in Physiology Education, 34(3), 150-155.

Detlor, B., Booker, L., Serenko, A., \& Julien, H. (2012). Student perceptions of information literacy instruction: The importance of active learning. Education for Information, 29(2), 147-161.

Donohoe, H.M. and Needham, R.D. (2009). Moving best practice forward: Delphi characteristics, advantages, potential problems, and solutions. International Journal of Tourism Research, 11, 415-437.

Dresselhaus, A., \& Shrode, F. (2012). Mobile technologies \& academics: Do students use mobile technologies in their academic lives and are librarians ready to meet this challenge? Information Technology \& Libraries, 31(2), 82-101.

Farrell, J.J., Moog, R.S., \& Spencer, J.N. (1999). A guided inquiry general chemistry course. Journal of Chemical Education, 76(4), 570-574.

Foundational Studies Program, Boise State University. (2013). University learning outcomes. Retrieved from http://academics.boisestate.edu/fsp/university-learning-outcomes/

Gibeault, M. J. (2013). Using iPads to facilitate library instruction sessions in a SCALE-UP classroom. UNC Chapel Hill Theses, 7.

Hale, D. and Mullen, L.G. (2009). Designing Process-Oriented Guided-Inquiry activities: A new innovation for marketing classes. Marketing Education Review, 19(1), 73-80. 
Hanson, D. and Wolfskill, T. (2000). Process workshops: A new model for instruction. Journal of Chemical Education, 77(1), 120-130.

Hegarty, N., Carbery, A., \& Hurley, T. (2009). Learning by doing: Re-designing the first year information literacy programme at Waterford Institute of Technology (WIT) Libraries. Journal of Information Literacy, 3(2), 73-87.

Hein, S.M. (2012). Positive impacts of using POGIL in organic chemistry," Journal of Chemical Education, 89(7), 860-64.

Jacobson, T. E. (2011). Team-based Learning in an information literacy course. Communications in Information Literacy, 5(2), 82-101.

Johnson, C. (2011). Activities using Process Oriented Guided Inquiry Learning (POGIL) in the foreign language classroom. Die Unterrichtspraxis / Teaching German, 44(1), 30-38.

Johnson, C. M., McCord, S. K., \& Walter, S. (2003). Instructional outreach across the curriculum: Enhancing the liaison role at a research university. Reference Librarian, 39(82), 19-37. Jones, G. F. (2009). An inquiry-based learning approach to teaching information retrieval. Information Retrieval, 12(2), 148-161. doi:10.1007/s10791-009-9088-x

Lewis, S.E. and Lewis, J.E. (2005). Departing from lectures: An evaluation of a peer-led guided inquiry alternative. Journal of Chemical Education, 82(1), 135-139.

Loo, J. (2013). Guided and team-based learning for chemical information literacy. Journal of Academic Librarianship, 39(3), 252-259. 
McKinney, P., Jones, M., \& Turkington, S. (2011). Information literacy through inquiry: A level one psychology module at the University of Sheffield. Aslib Proceedings, 63(2/3), 221-240. doi:10.1108/00012531111135673

Meriam Library, California State University, Chico. (2010). Evaluating information: Applying the CRAAP test. Retrieved from http://www.csuchico.edu/lins/handouts/eval websites.pdf

Miller, W. (2012). iTeaching and learning. Library Technology Reports, 48(8), 54-59.

Mitchell, C. and Hiatt, D. (2010). Using POGIL techniques in an information literacy curriculum." Journal of Academic Librarianship, 36(6), 539-42.

Moog, R.S. \& Spencer, J.N. (2008). POGIL: An overview. In R.S. Moog \& J.N. Spencer (Eds.), Processoriented guided inquiry learning (pp. 1-13). Washington, DC: American Chemical Society.

Moog, R.S., Creegan, F.J., Hanson, D.M., Spencer, J.N., \& Straumanis, A.R. (2006). Process-Oriented Guided Inquiry Learning: POGIL and the POGIL project. Metropolitan Universities, 17(4), 41-52.

Peters, M. C. (2011). Beyond Google: Integrating chemical information into the undergraduate chemistry and biochemistry curriculum. Science \& Technology Libraries, 30(1), 80-88.

Sharman, A., \& Walsh, A. (2012). Roving librarian at a mid-sized, UK-based University. Library Technology Reports, 48(8), 28-34.

Shumaker, D. (2009). Who let the librarians out?: Embedded librarianship and the library manager. Reference \& User Services Quarterly, 48(3), 239-257. 
Thull, J. \& Hansen, M.A. (2009). Academic library liaison programs in U.S. libraries: Methods and benefits. New Library World 110 (11/12), 529-540.

Writing process skill goals for POGIL activities. (n.d.). The POGIL Project. Retrieved from $\underline{\text { http://www.pogil.org/uploads/media items/writing-process-skill-goals.original.pdf }}$ 